\title{
Research on emergency management of College Students
}

\author{
Wang Xiangwei ${ }^{1}$ \\ ${ }^{1}$ School of Economy and Management, Shenyang aerospace university Shenyang, P.R.China
}

\begin{abstract}
In recent years, the number of College Students' emergencies in China is gradually increasing, which is bound to affect the stability and development of colleges and society. This paper takes the college students' emergency in Liaoning Province as an example, analyzes the current situation of College Students' emergency and emergency management mechanism in China, and puts forward countermeasures and suggestions for college students' emergency management mechanism in China. The countermeasures include: to cultivate the crisis awareness of students and university staff; to establish and improve the prevention and early warning mechanism of College Students' emergencies; to strengthen the legal construction of colleges and universities, and to promote the legalization of emergency management in Colleges and universities.
\end{abstract}

\section{Introduction}

With the changes of international and domestic political, economic, cultural and social environment and the deepening of China's higher education reform, the management of college students is facing many new problems. College emergencies also present new features such as "high degree of social concern", "fast information dissemination", "easy to spread to the society". SARS caused panic among some college students in 2003. Students jumped from buildings and committed suicide in Colleges in Beijing and Guangdong in 2009. A female student in a college in Beijing killed her classmates in 2010. A student in a College in Shandong occupied a seat and jammed doors and windows in 2013. Xi Jinping held the Twelfth Meeting of the Central Committee for deepening reform in 2019. He stressed: improving the major epidemic prevention and control system and improving the public health of the state. These sudden events not only cause the high attention of all sectors of society, but also give a warning to the society - the emergency events that colleges and universities need to deal with are on the rise in recent years. Once the incident occurs, if the rapid response and emergency response of all parties are not in place, it will directly or indirectly affect the safety of teachers and students, normal learning and life, and cause or may cause serious social harm. The research on the quick response mechanism of College Students' emergencies has become an important topic to strengthen the ideological and political construction in Colleges and Universities.

\section{Ease of Use}

\subsection{The current situation of College Students' emergencies in China.}

Because there are more than 100 colleges and universities in Liaoning Province, and the number of college students reaches more than 1 million, which is representative in the whole country, so we take college students' emergency in Liaoning Province as an example. In the past five years, there have been 205 college students' emergencies with great influence in Liaoning Province, including 55 accidents and disasters, 51 public health emergencies, 91 social security emergencies, 8 other social security emergencies and 0 natural disaster emergencies. Due to the geographical location of Liaoning Province, the incidence of natural disasters is very low, few natural disasters can affect campus emergencies, so in the past five years, there are no emergencies caused by natural disasters. From the above data, we can see that social security incidents account for a large proportion in all kinds of emergencies of college students in Liaoning Province, accounting for $44.39 \%$ of the total number of College Students' emergencies in Liaoning Province in the past five years, followed by accidents and disasters, accounting for $26.8 \%$ of the total. Figure 1 shows the trend of College Students' emergencies in Liaoning Province in recent five years.

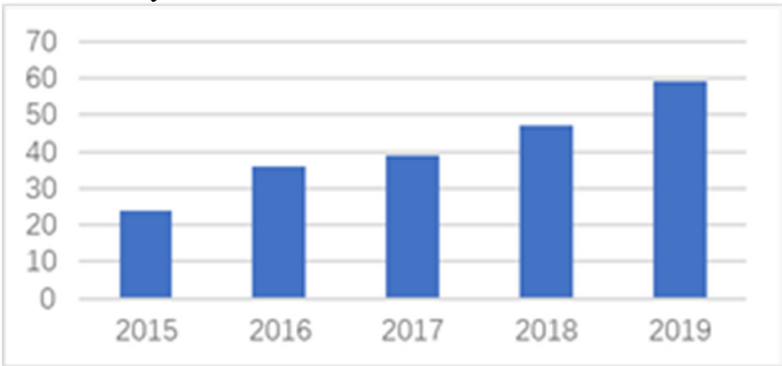

Fig1. Trend of College Students' emergency events in Liaoning Province in recent 5 years (Data is from network statistics)

\subsection{Current situation of emergency management mechanism of college students in China.}


At the national level, on April 16, 2018, the Ministry of emergency management of the people's Republic of China was officially established. The emergency management department is responsible for organizing the preparation of the national overall emergency plan and plan, guiding all departments in all regions to deal with emergencies, and promoting the construction of the emergency plan system and the drill of the plan. Establish a disaster reporting system and release the disaster situation in a unified way, coordinate the construction of emergency forces and material reserves and dispatch them in a unified way during disaster relief, organize the construction of disaster relief system, guide the emergency rescue of work safety and natural disasters, and undertake the work of the national response headquarters for particularly major disasters. To guide the prevention and control of fire, flood and drought disasters and geological disasters. To be responsible for the comprehensive supervision and management of work safety and the supervision and management of work safety in the industry, mining and trade industries.

At the level of colleges and universities, in response to some emergencies, many colleges and universities have established corresponding emergency management organizations, and gradually formed their own emergency response mechanism for public emergencies. For example, novel coronavirus pneumonia broke out in 2020, and many universities have formulated emergency response mechanism and plan for public emergencies. At present, the frequent emergencies in Colleges and universities and the crises they bring highlight the necessity and urgency of improving the emergency response system in Colleges and universities. The facilities and equipment, human resources and financial resources, communication and transportation facilities of emergency rescue in most colleges and universities in China have been continuously enriched. At the same time, the information communication and cooperation exercise with the social emergency rescue system have also been significantly strengthened.

\section{Analysis of the problems and causes of the emergency management mechanism in Colleges and universities in China.}

\subsection{The awareness of crisis management is relatively weak.}

At present, university leaders and managers mainly focus on how to expand enrollment scale, increase school space, improve school level, expand school influence and so on. There is a phenomenon of "say it is important, think it is necessary, and don't be busy" for potential crisis management problems. Even if there are some crisis events, they tend to hold major events The attitude of small and trivial matters to deal with the crisis is not to cure the symptoms, some root causes have not been eradicated, and problems in crisis management can not be considered from a deep level. Once major crisis events occur, we can not repent, resulting in a great passive situation.

\subsection{Imperfect crisis management system.}

In recent years, crisis management has been gradually concerned by all levels of education administrative departments and colleges and universities, but a complete crisis management system has not yet been formed. Most colleges and universities lack the ability of early warning of emergencies. Although some colleges and universities have established crisis management institutions and formulated some emergency plans, they are often just in the form of coping with inspection. Many colleges and universities have not really focused on crisis management as a normal work, and have not formed a perfect system in the prevention, response and disposal of crisis management. It is only after the occurrence of the crisis that we can make up for the shortage temporarily. We can play the role of coordination and leadership of the crisis management organization temporarily. It is easy to have the phenomenon of headache and foot pain. The lack of specialized institutions and personnel to study the emergence, prevention, disposal, summary and other aspects of the crisis makes the top-level concept of crisis management not in place and lacks necessary organizational guarantee.

\subsection{Lack of legal support for crisis management in Colleges and universities.}

In the current law of China, there is still a lack of complete and unified law on college student crisis management. There is no corresponding legal support for crisis management for Colleges and universities. For the crisis management events on campus, there is no clear legal means to clarify the role of the government departments, the responsibilities of the school, the standards of specific compensation for the victims, and the legal responsibilities of the crisis participants. At present, most of the injuries on campus are carried out by referring to the measures for dealing with students' injuries issued by the Ministry of education. However, the "measures for dealing with student injury accidents" is only a department regulation formulated by the Ministry of education, which has relatively low legal status and lacks authority.

\subsection{There is a lack of news spokesman system in olleges and universities.}

Many Colleges and Universities lack of new spokesman system. Locking information will only spread rumors and all kinds of false information, which will have a negative impact that is difficult to control, and even cause an unfavourable situation difficult to control. Therefore, local colleges and universities should establish and improve the spokesman system, in case of emergencies, the university should find out the truth of the incident in time, and the spokesman should use it objectively, accurately, steadily and orderly campus network or to the news media to release news about the 
incident; for the incident that is difficult to find out the truth at the moment, it should also be timely. We should publicize the basic facts and progress of the incident, control the direction of public opinion, and eliminate the speculation and rumors of unknown truth Crisis wins time and public opinion support.

Western countries have consistently claimed that the media are "public tools of society" and "the fourth right", enjoying absolute "freedom of the press". At present, some people in the press are deeply influenced by this trend of thought and blindly advocate the freedom of the Western press. In addition, some media practitioners are not of high quality, and they focus on novelty hunting and reporting negative news to attract the public's attention. What's more, there are some fake journalists in the society. In addition to reporting some false news, they don't ask universities to ask for money or material, but they give more The correct handling of emergencies in Colleges and universities has increased the trouble.

\section{College students' emergency management countermeasures.}

\subsection{Cultivate the crisis awareness of students and university staff.}

Crisis awareness is very important for both students and administrators of colleges and universities. Colleges and universities should strengthen safety education to improve the crisis awareness of teachers and students, so as to prevent the occurrence of emergencies in Colleges and universities. Therefore, it requires each university to establish a perfect safety education mechanism, to carry out regular college emergency safety education for teachers and students, in order to strengthen their understanding of College emergency, so as to do a good job in event prevention and emergency response. Colleges and universities can carry out a variety of safety education activities (such as food safety education, laws and regulations education, mental health education, personal safety education, traffic safety education, etc.) to improve the effect of education, so as to nip college emergencies in the bud.

\subsection{Establish and improve the prevention and early warning mechanism of College Students' emergencies.}

Prevention and early warning mechanism refers to the process of systematic assessment of unstable factors, prevention and warning of all kinds of potential threats and hazards, and early intervention to eliminate emergencies in the bud. Sound prevention and early warning mechanism is the key to emergency management, which can effectively improve the initiative to deal with emergencies. Therefore, colleges and universities should gradually establish and improve the prevention and early warning mechanism of emergencies according to their own characteristics. A perfect information collection system is the premise of early warning. Therefore, colleges and universities should collect information from multiple channels and channels in an all-round way. Figure2 showed the College students Emergency Warning Center.

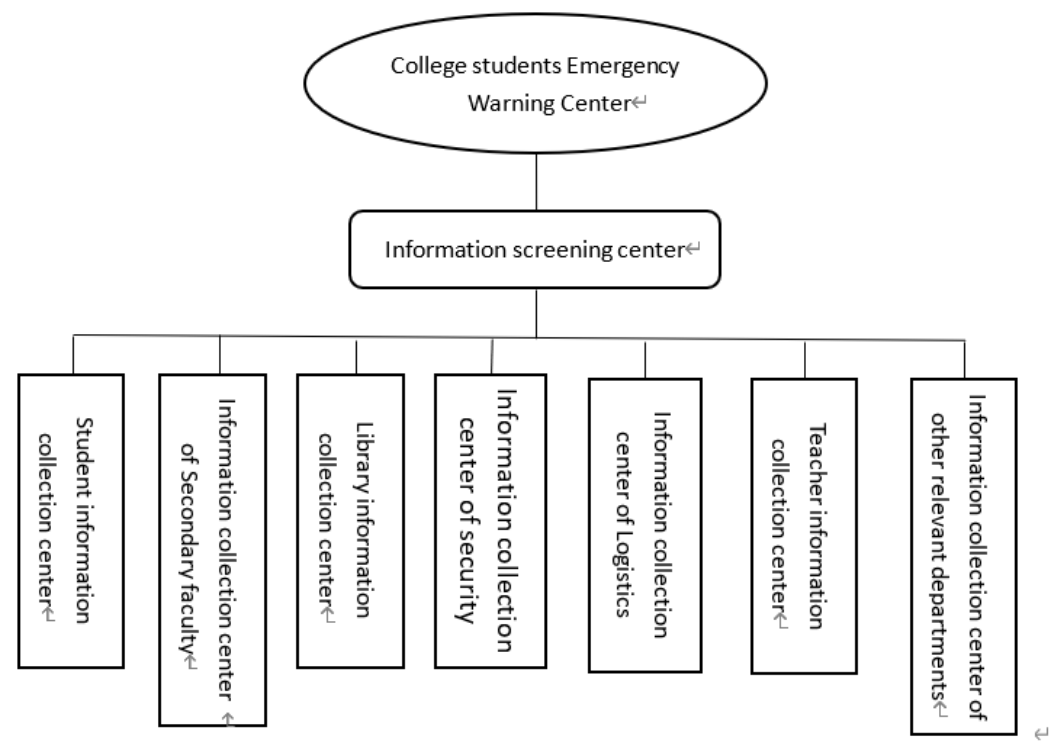

Figure2 the College students Emergency Warning Center

\subsection{Strengthen the construction of legal system in Colleges and universities, and promote the legalization of emergency management in Colleges and universities.}

Compared with general public emergencies, University emergencies have the characteristics of both general public emergencies and their own. Therefore, the university emergency management should not only follow the general public emergency law, but also follow the special legal provisions. College emergency legal system belongs to the abnormal legal system, which is the sum of the legal norms and principles about how to deal with the social relations between the state power and the school rights, between the school rights and the rights of teachers 
and students and staff in the school emergency. As a legal means to prevent, control and deal with emergencies, the university emergency management legal system should be an important part of the national emergency legal system. According to the characteristics of the construction of the socialist legal system and the needs of the emergency work in our country, we should intensify the research on the emergency legal system, build the emergency legal system, clarify the characteristics of the emergency work in Colleges and universities according to the requirements of the actual emergency work in Colleges and Universities, the different functions and powers of colleges and Universities under different emergency conditions and the legal responsibilities of colleges and universities, Strive to make the emergency work of colleges and universities move towards the rule of law in an all-round way.

\subsection{Local colleges and universities should strengthen effective communication with news media.}

Effectively communicate with the media to local clleges and universities Dealing with emergencies has a great impact and role. Public opinion control and media public relations are the most complex and difficult links in local colleges and universities, and also the key to the successful disposal of emergencies. The "double-edged sword" function of the media makes it necessary for colleges and universities to intelligently control public opinion and take the initiative in media public relations. The purpose of public opinion control is to block information and release information correctly. When controlling public opinion, local colleges and universities should first analyze and screen public opinion information, analyze and judge the interests of colleges and universities, and correctly guide the media to make correct reports by effectively combing the information of emergencies; in addition, local colleges and universities can also use the media to stop some rumors, clarify their own attitude and guide them The public has a positive view of colleges and universities, so as to avoid making the media report distorted news and speculative reports, which will affect the image of local colleges and universities.

\section{Conclusion}

College emergency management can not simply rely on a department to work alone, it needs all departments, all personnel and even the whole social system linkage. Only in this way can we control the events that have not occurred in the shortest time in the bud, control the emergencies that have occurred in a certain range, and reduce their damage and impact to the lowest point.

\section{Acknowledgment}

The paper is supported by 2019 Liaoning Social Science Planning Fund (Special project of Ideological and political in Colleges and Universities), the Project number is L19BSZ066.

This paper is also supported by the project of 2019
Liaoning Provincial Department of education, the project number is JYT19070.

\section{References}

1. Jimerson, Shane: Broek, StephenE. Pleteher, SarahW(2005). An Integrated Model of School Crisis Prepared nessand Intervention. Ashared Foundation to Faeilitat international Crisis Intervention. Sage Publieations.

2. Xie, Y., Qiao, R., Shao, G. S. and Chen, H., "Research on Chinese Social Media Users' Communication Behaviors Dur-ing Public Emergency Events", Telematics and Informatics, 2017, 34(3).

3. Lee, K., "How the Hong Kong Government Lost the Public Trust in SARS: Insights for Government Communication in A Health Crisis", Public Relations Review, 2009, 35(1).

4. Shirky, C., Here Comes Everybody: The Power of Organizing Without Organizations, New York: Penguin Press, 2008.

5. Barton L. Knox. Trauma in the Aftermath of Organizational Catastrophe: Supervisors [M]. London: Prentil-HallInternationa11996.19-20.

6. Kramer L. Barton (When the Crisis is Orchestrated: Corporate Campaigns and Their Origins (New Avenues in Risk and Crisis Management). [M] Charles C. Thomas Publisher Ltd. 1996.

7. Michael E. Chatterley and Linda McJannet, Management Communication: Principles and Practice [M]. New Yapok: Harvard Business School Press. 1997. 